\title{
Spatial Analysis of Distribution Pattern of Covid-19 Cases in Batang Regency
}

\author{
Bangun I R Harsritanto*, Satrio Nugroho ${ }^{2}$, and Favian Dewanta ${ }^{1}$ \\ ${ }^{1}$ Architecture Department, Engineering Faculty, Universitas Diponegoro, Semarang, Indonesia \\ ${ }^{2}$ School of Electrical Engineering, Telkom University, Bandung, Indonesia
}

\begin{abstract}
The pandemic of covid-19 had brought many responses from every institution. As one of the religious institutions, Mosque was reported various adaptations in aims to support their activities. The adaptations were related to strategies in physical designs, health protocols implementations, and embedded technologies. The interaction between each strategy also shown different patterns of mosques' innovation in serving their communities. These mosque studies consist of literature reviews and site observations to elaborate the communal mosque adaptations against the pandemic. The shifting of mosques is closely related to environments and technologies.
\end{abstract}

\section{Introduction}

Mosques have become a building for multifunction at different periods for Muslims, such as a religious ceremony, performing salat, reciting Quran, communal social interaction, etc. Hence, there are many designs strategy of adaptation and interaction shall be facilitated on it [1] The design and many facilities of mosques closely linked to contextual site response, acculturation interactions and climate condition approaches [2]. The mosque shall be designed to form the principal prayer (salat) space with an orientation toward qibla (the bait Allah/Kabah at Mecca) and room of ablution (wudhu) to do the washing part of a body as a requirement before worshiping activities [2].

Muslim communities had built many mosques for their group or public use all over the earth as their everyday need in communal prayer space. The mosque also became a religious identity in Muslim countries as their position of the world population [3]. As the world's biggest Muslim country, Indonesia has a regulation by the Ministry of Public WorksHousing Settlement decree no.14/2017 that order each building to provide a prayer room. The decree also strictly stated that masjid must install: exact orientation to qibla, a separation between worshiping and standard room, and proper conditions [4].

In late 2019 The initial case of COVID-19 was reported in Wuhan, China, and then became every country in the world's serious problem [5-7]. The World Health Organization (WHO), as a division of the United Nations (UN), officially published that novel Corona Virus Disease 19 (COVID-19) as a global pandemic in March 2020 as the worldwide spreading of COVID-19 on all continents [8,9]. Due to date 29th of May 2021, COVID-19

* Corresponding author: bangunirh@arsitektur.undip.ac.id 
has spread rapidly through about 222 countries with the case of positive infected 170,256,454 patients, case of recovered $152,148,821$ patients, and case of death 3,540,426 persons [10]

Many countries have strictly force lockdown laws or night curfews to minimize the spreading [11], as they learned from the previous pandemic on earth [12]. However, there are still various responses of people toward the regulation that still not applying a lock down situation because the lockdown brought local termination of public and communal activities and shut the entrance-exit border that may destroy the community itself [12]. All countries also supplied the medical stuff (sanitary unit, medical mask, face/mouth shield, etc.), various COVID-19 tests (antibody, antigen, PCR), curative medical treatments, and some researchdeep study to respond to this condition [13]. The pandemic brought impact all daily life in long terms [14] such as process of educations [15] tourism on international or domestic size [16], and not least the religious sector [17].

Indonesia's reported initial case of Depok regency COVID-19 with two positive suspects on March 2nd, 2020 [17, 18]. Starting from that date, the virus COVID-19 has to be avoided with physical and social distancing amongst us [19]. In January 2021, there were 14,518 new cases, which is the highest case in Indonesia [20]. Learned from that, the Indonesia government and Islam scholars released health-based protocols to do religious activities (such: salat, prayers, communal ritual) at home to support the government regulation no.21/2020 about Large Scale Social Limitation (PSBB) for Corona Virus Disease 2019 (COVID-19) Pandemic Response [21]. One of Indonesia's Muslim Representative Organizations called Majelis Ulama Indonesia (MUI) had issued a fatwa (religious law) no.14/2020 about Pandemic COVID-19 response on Worship Protocols to cut COVID-19 spreading's [22]. By those formal constitutions and religious law notice, all Muslims must embrace the new normal adaptation to keep every ummah (believers) healthy and away from COVID-19 [17]. The adaptations confront directly from common worship, which performed since the Rasulullah era. However, the medical problem shall be bridge between tradition and reality [22].

This research aims to report mosque's responses and explain the adaptation evidence on this COVID-19 pandemic by the descriptive-analytic procedure. The research objects are several mosques that still open and respond to a communal worshiping activity (ibadah jamaat).

\section{Methods}

\subsection{Literature Study}

This Literature study is the primary method for identifying and analyzing the phenomena. Some literature research on COVID-19 situations, the mosque, and the preventive efforts was resumed with the object mosque that was still open and responded to communal prayer (ibadah jamaat) during pandemics.

\subsection{Site Observation}

The many sites' direct observations were done to collect specific communal mosques material, especially their various adaptation against COVID-19 pandemic health protocols. The documentation was captured by digital (not analogy) tools, such as smartphone cameras and laser measure meters to maintain precision. 


\subsection{Descriptive Analysis}

Analytic descriptive becomes the primary analysis in explain and relating each finding. Physical/architectural design and health protocols. The descriptive is an effort in explaining phenomena with authors' subjects, such: architectural design, Islamic regulation (fiqh), social (muamallah), and sciences.

\section{Material and Discussion}

\subsection{Regulation and Conditionings}

As mentioned in the previous section, MUI had issued fatwa no.14/2020 about Worship Protocols in Pandemic COVID-19 [22], in detail areas such Campus like Undip, Rector also issued the note no. 20/UN.7.P/SE/2020 [23]. The operating regulations are also strongly stated by mosque administrators (Takmir) via an announcement on the mosque gates [24] (figure 1 right) or social media news (figure 1 left). It was a mandatory message to be informed by the mosque as government law. Therefore. Worshipper (jamaat) may understand the condition of the mosque, whether: the mosque is open or close, ready to perform salat jamaat (communal prayer) and prepare to do prayer on that mosque. Minister of Health and Mosque administrator group [25] conditioned that people shall be minimized in mosque activities.

The pre-conditions of mosque visit are taking wudlu (ablution) and wearing medical mask. In front of mosque, there will officers who perform body temperature and mask checking. The worshippers who are collided with sickness and some symptoms, were not suggested to pray in home and isolate their self. During the prayer, worshipers are not allowed to remove mask, touch the mosque utilities, performing physical contacts, making crowd more than $50 \%$ of capacities, and performing salat in shorter than $1 \mathrm{~m}$ [24]. However, the present socio-political environment made discussions of the health effects of COVID-19, additional information from public health messaging may be unable to change mass preferences or behaviours [26].
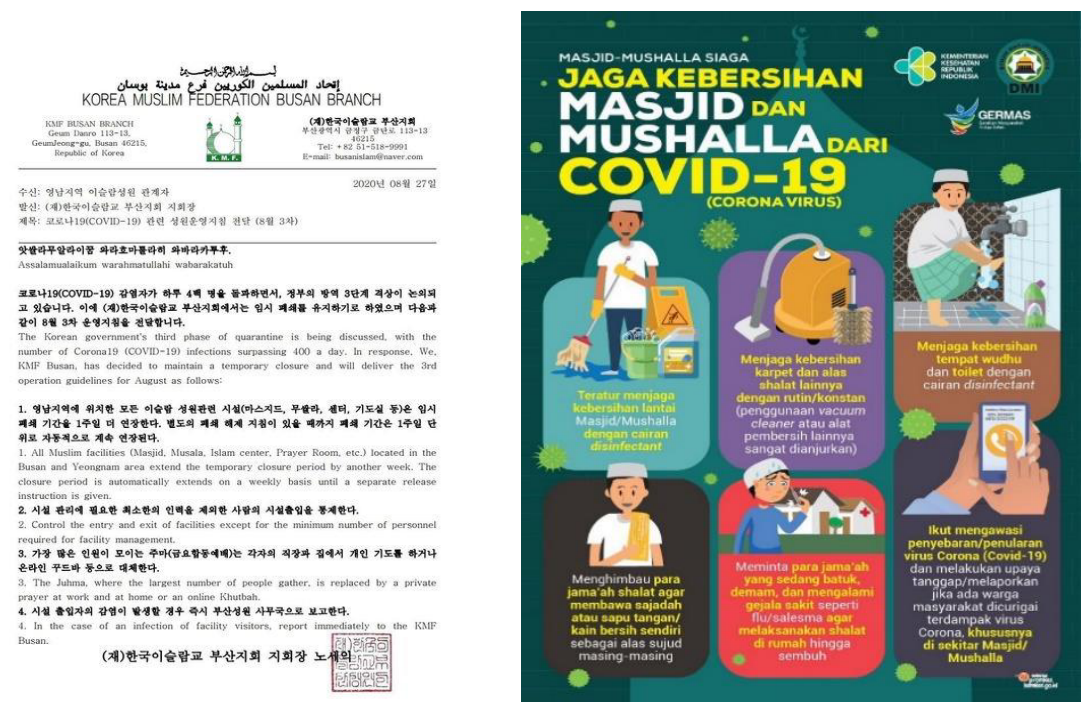

Fig. 1. Masjid Annoncement about Health Protocol (left: mosque closing [25] ; right: activities protocol in mosque [24]). 


\subsection{Ablution Device's Innovation}

The ablution design affects the water consume so tap design can help the water saving. It can also propose activation with legs (feet or knees) instead of opening taps with hands, and it helps decrease water waste (see figure 2 left). Solving the problem of excess water consumption can be provided by a good tap control design. We can introduce a new design for ablution tub or other innovations such as automatic tap (see figure 2 right). The automatic tap may reduce physical contact with mosque utilities, which may lower the COVID-19 spreading [26].

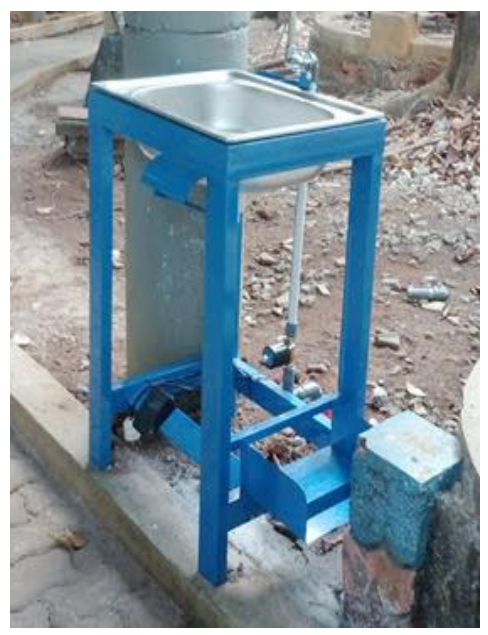

Fig. 2. Ablution tap design (knee activation).

Table 1. Types of Tap [27].

\begin{tabular}{|c|c|c|}
\hline Tap Type & $\begin{array}{c}\text { Average total ablution } \\
\text { time (s) }\end{array}$ & $\begin{array}{c}\text { Percentage of wasted } \\
\text { water (\%) }\end{array}$ \\
\hline Mechanical knobs-tap & 59.9 & 47 \\
\hline Mixing short neck-tap & 57.2 & 42 \\
\hline Mixing high neck-tap & 42.8 & 38 \\
\hline Mechanical push button-tap & 49.8 & 30.3 \\
\hline Automatic tap & 49.4 & \\
\hline
\end{tabular}

\subsection{Signage of health protocols}

Figure 1 left shown that mosques in South Korea inform in bilingual cause the worshippers (jamaat) are not only Korean but also foreigners, and right shown that Indonesia mosque announced in words and graphics to bring more information's. The signage is essential to promote health protocols. The distant physical signage while doing salat is also being installed in the prayer room. Most mosques use (X) signs to represent an unavailable prayer area, while some mosques also put footprint stickers to locate the exact prayer area (figure 3). 
However, some people may not be aware of this signage, and even more, they were making no physical distancing at all [28]. Most closely salat people are keeping their behavior before the pandemic and argue with hadiths. It has to be a discussable problem of many mahzab in Islam about a particular situation and scholar opinions [29].

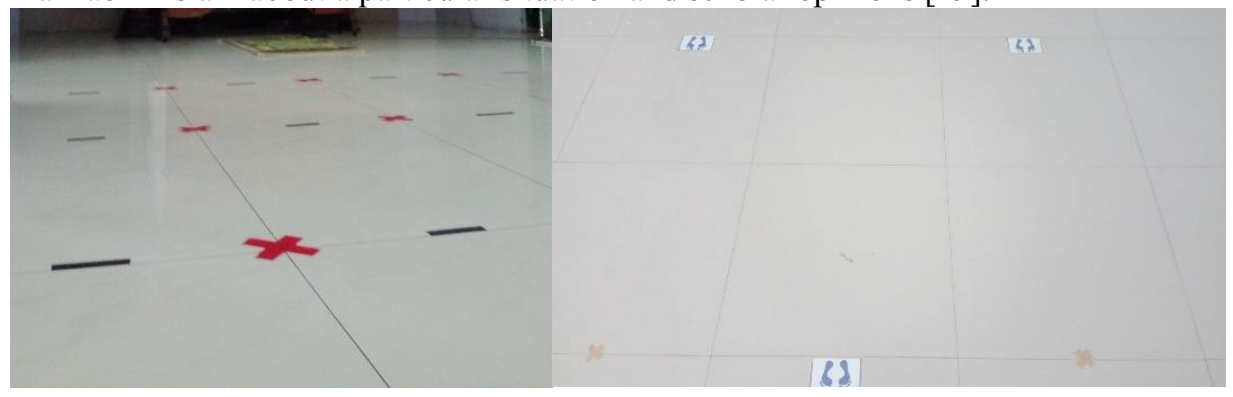

Fig. 3. Physical Sistancing Signage.

\subsection{Cross Ventilation and Floor Mat Roll}

Every mosque in Indonesia has to roll up its carpets and open the windows/doors during communal prayer time. Those conditions were ordered by MUI and the ministry of health's regulations. So, starting in 2020, the mosque applied the regulation and showed the situation like Figure 4 . The carpets and another mat should not be used by multiple users that may spread the COVID-19. Some Takmir said that that condition made them clean the mosque floor more frequently. The opening of windows and doors make not only good cross ventilation but also dust-dirt collectors. Furthermore, the rolled mat/carpet (sajadah) made the mat material smelly and prone to destruction by natural humidity.
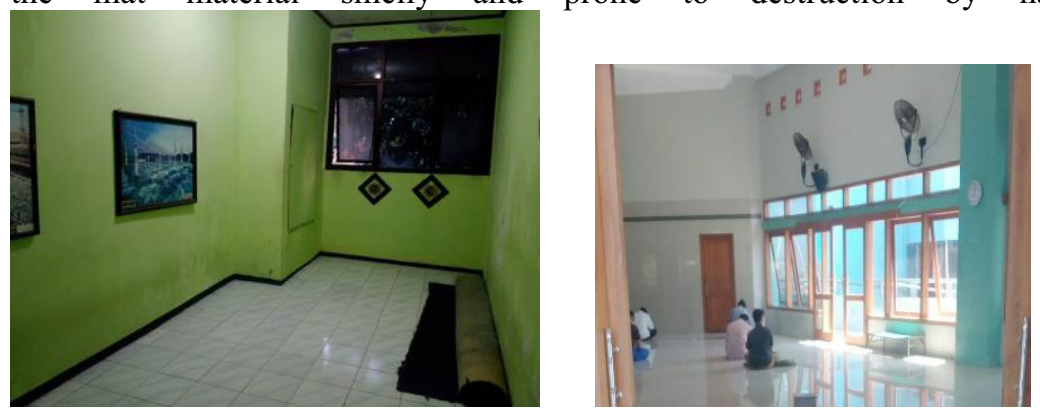

Fig. 4. Interior of the mosque adaptation (left: rolled up mat ; right: Windows and Doors opening).

\subsection{Prayer space expansion}

As been told in the regulation section, the capacity of the mosque must be reduced in half. This regulation made some Takmirs choose to close the mosque (figure 1 left), and some perform prayer space expansion (figure 5). The expansion was not the direct impact of health protocols as being done before, but with a $50 \%$ capacity point, it became reason to expand the prayer space of the mosque. The expansion is usually performed by mosques with the front facade that does not direct to the west (qibla) that clause related to mihrab movement to the expansion area for the west facing mosque [1]. The expansion usually uses street or public space behind or beside the mosque. 


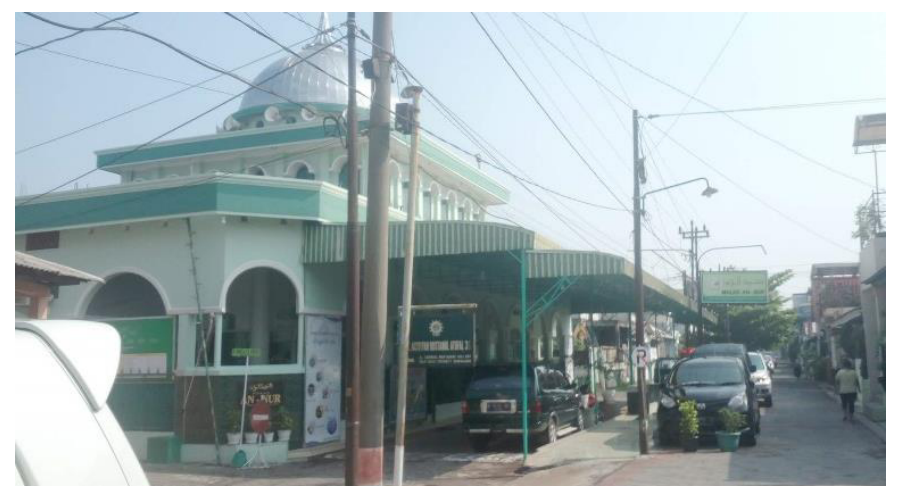

Fig. 5. Mosque Expansion.

\subsection{Future challenges against The Protocol}

The present socio-political situation made some dilemma of the health protocol against COVID-19 and mass preferences or behaviors in the past. The previous adaptation built by the mosque would mean nothing if worshipers did not change their mindset toward COVID19 and communities. It was no surprise that people still think that COVID-19 is a global conspiracy or COVID-19 can be surpassed in short periods [28, 30]. The current condition of careless people may result in clusters of religious activities and spread wider if there are no control or trace suspects $[31,32]$.

The physical design could not anticipate and force people's desire, so socialization of COVID-19 prevention shall be massively spread. Some religious or spiritual leaders need to bespoke persons to suggest their followers obey the health protocols. In some cases, the rapid change of regulation toward mosques made worshipers confused and anger also negatively impacted the mosque and COVID-19 prevention efforts [33, 34].

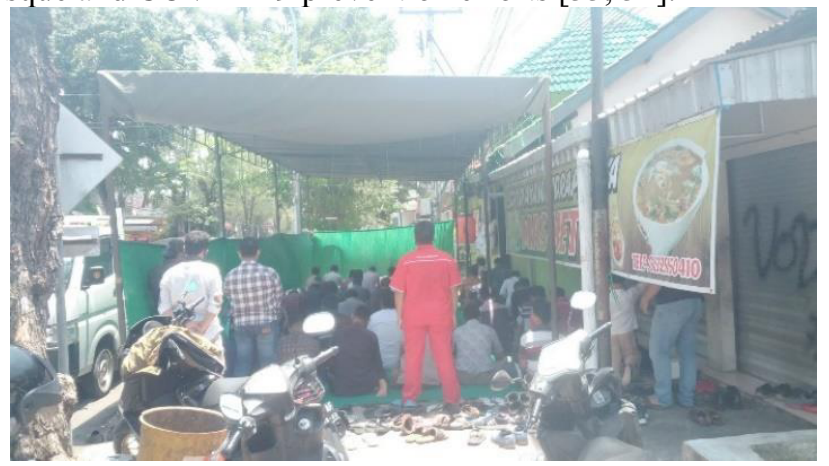

Fig. 6. Tread against the health protocol on mosque.

\section{Conclusion}

Pandemic COVID-19 has made many changes to the environmental design approach. As part of a public building, the mosque is adapting a new regular habit on their design developments. Regulation, health protocols, global news, social change, and environmental conditions toward pandemics have force mosques to: innovate their devices, apply basic passive design, and expand some spaces. However, the challenges of pandemic COVID-19 are still running in this world. The design developments, technology innovations, and most important, "social engineering" also need to be encouraged by all people as the response to pandemic. 
This research was financially supported by The Faculty of Engineering, Diponegoro University, Indonesia through Strategic Research Grant 2021.

\section{References}

1. Harsritanto, B. I. Radityo, S. Nugroho, F. Dewanta, A. R. Prabowo, Mosque design strategy for energy and water saving, Open Engineering, 11(1), 723-33 (2021)

2. A. Atmaca, G. Z. Gedik, Evaluation of mosques in terms of thermal comfort and energy consumption in a temperate-humid climate, Energy \& Buildings, 195, 195-204 (2019)

3. B. I. R. Harsritanto, Pengenalan arsitektur masjid, Suara Merdeka, (2018)

4. I. Abdul-Matin, Green deen: What islam teaches about protecting the planet, (BerrettKoehler Publishers San Francisco, 2010)

5. Ministry Settlement, Persyaratan kemudahan bangunan gedung permen PUPR no.14/2017, (Kementrian Pekerjaan Umum dan Perumahan Rakyat Jakarta, 2017)

6. M. K. Daga, N. Kumar, J. Aarthi, G. Mawari, S. Garg, I. Rohatgi, From SARS-CoV to coronavirus disease 2019 (COVID-19)-A brief review, Journal of Advanced Research in Medicine, (2019)

7. N. Woznitza, S. S. Hare, A. Nair, Covid-19 pandemic: Summary of current and emerging issues for radiographers, Work, 20, (2019)

8. Y.-R. Guo, Q.-D. Cao, Z.-S. Hong, Y.-Y. Tan, S.-D. Chen, H.-J. Jin, K.-S. Tan, D.-Y. Wang, Y. Yan, The Origin, transmission and clinical therapies on coronavirus disease 2019 (COVID-19) outbreak - An update on the status, Military Medical Research, 7(11), (2020)

9. D. Cucinotta, M. Vanelli, WHO declares COVID-19 a pandemic, Acta Bio-Medica: Atenei Parmensis, 91(1), 157-160 (2020)

10. Worldmeter, Retrieved from https:/www.worldometers.info/coronavirus/

11. A. Spinelli, G. Pellino, COVID-19 pandemic: perspectives on an unfolding crisis, The British Journal of Surgery, (2020)

12. Wilder-Smith, D. O. Freedman, Isolation, quarantine, social distancing and community containment: pivotal role for old-style public health measures in the novel coronavirus (2019-nCoV) outbreak, Journal of Travel Medicine, 27(2), (2020)

13. D. Darmawan, Sikap keberagamaan masyarakat muslim menghadapi Covid-19 religious, Jurnal Studi Agama-Agama dan Lintas Budaya, 4(2), 115-125 (2020)

14. Roosa et al., Real-time forecasts of the COVID-19 epidemic in China from February 5th to February 24th, 2020 Infectious Disease Modelling, 5, 256-263 (2020)

15. A. Abidah, H. N. Hidaayatullaah, R. M. Simamora, D. Fehabutar, L. Mutakinati, The Impact of covid-19 to Indonesian education and its relation to the philosophy of "Merdeka Belajar", SiPoSE: Studies in Philosophy of Science and Education, 1(1), 3849 (2020)

16. S. Gössling, D. Scott, C. M. Hall, Pandemics, tourism and global change: a rapid assessment of COVID19, Journal of Sustainable Tourism, 1-20 (2020)

17. Harsritanto, I. R. Bangun, S. Nugroho, F. Dewanta, Undesignated Academic Mosque Response Toward COVID--19 Pandemic, E3S Web of Conferences 202, 07056 (2020)

18. R. Djalante, J. Lassa, D. Setiamarga, A. Sudjatma, M. Indrawan, B. Haryanto, C. Mahfud, M. S. Sinapoy, S. Djalante, I. Rafliana, L. A. Gunawan, G. A. K. Surtiari, H. 
Warsilah, Review and analysis of current responses to COVID-19 in Indonesia: Period of January to March 2020, Progress in Disaster Science, 6, 100091 (2020)

19. J. Martha, Pemanfaatan diplomasi publik oleh Indonesia dalam krisis Covid-19, Jurnal Ilmiah Hubungan Internasional, 121-130 (2020)

20. CSSEGISandData, (2020), JHU CSSE COVID-19 Dataset, Retrieved from https://github.com/CSSEGISandData/COVID-19/tree/master/csse_covid_19_data

21. S. Chen, J. Yang, W. Yang, C. Wang, T. Bärnighausen, COVID-19 control in China during mass population movements at New Year, The Lancet, 395(10226), 764-766 (2020)

22. Pemerintah Indonesia, Peraturan Pemerintah (PP) No. 21/2020 - Pembatasan Sosial Berskala Besar (PSBB) Dalam Rangka Percepatan Penanganan COVID-19, (2020)

23. Fatwa No. 14 Tahun 2020 - Penyelenggaraan ibadah dalam situasi terjadi wabah covid19, (Komisi Fatwa MUI Jakarta, 2020)

24. SURAT EDARAN REKTOR UNIVERSITAS DIPONEGORO Nomor: 27/UN7.P/SE/2020 tentang kebijakan work from home di bulan puasa (2020)

25. Kementrian Kesehatan, (March, 2020), Retrieved from https://promkes.kemkes.go.id/flyerpencegahan-covid-19-di-masjid-dan-musholla

26. https://www.facebook.com/busanpumita

27. N. Kuipers, S. Mujani, T. Pepinsky, Encouraging Indonesians to pray from home during the COVID-19 Pandemic, J Exp Polit Sci, 1-12 (2020)

28. I. Budaiwi, A. Abdou, HVAC system operational strategies for reduced energy consumption in buildings with intermittent occupancy: The case of mosques, Energy Conversion and Management, 73, 37-50 (2013)

29. Supriatin, (June, 2020), Kemenag: Kami dapat laporan sejumlah jemaah salat jumat tidak jaga jarak, Retrieved from https://www.merdeka.com/peristiwa/kemenag-kamidapat-laporan-sejumlah-jemaah-salat-jumat-tidak-jaga-jarak.html

30. A. Nasir, SOCIAL distancing dalam saf salat berjamaah (Perbandingan ulama dalam mazhab), Mazahibuna 2.1, (2020)

31. M. Sallam, Conspiracy beliefs are associated with lower knowledge and higher anxiety levels regarding COVID-19 among students at the University of Jordan, International Journal of Environmental Research and Public Health, 17(14), MDPI AG, 4915 (2020)

32. CNN Indonesia, (May, 2021), 22 warga Bantul positif corona dari klaster salat tarawih, Retrieved from https://www.cnnindonesia.com/nasional/20210504090649-20638171/22-warga-bantul-positif-corona-dari-klaster-salat-tarawih

33. PijarOnline, (May, 2020), Cluster covid-19 waru, bukan karena buka kafan, tapi bermula tahlilan dan jumatan, Retrieved from https://pijaronline.net/cluster-covid-19waru-bukan-karena-buka-kafan-tapi-bermula-tahlilan-dan-jumatan

34. A. Al-Astewani, To open or close? COVID-19, mosques and the role of religious authority within the british muslim community: A Socio-legal analysis, Religions, 12(1), $11(2021)$

35. S. Yezli, A. Khan, COVID-19 pandemic: it is time to temporarily close places of worship and to suspend religious gatherings, Journal of Travel Medicine, 28(2), (2021) 